\title{
The Epidemiology and Demographics of Legg-Calvé-Perthes' Disease
}

\author{
Randall T. Loder ${ }^{1,2}$ and Elaine N. Skopelja ${ }^{3}$ \\ ${ }^{1}$ Section of Orthopedic Surgery, Riley Hospital for Children, ROC 4250, 705 Riley Hospital Drive, IN, Indianapolis 46202, USA \\ ${ }^{2}$ Department of Orthopaedic Surgery, Indiana University, Indianapolis, IN 46202, USA \\ ${ }^{3}$ Ruth Lilly Medical Library, School of Medicine, Indiana University, Indianapolis, IN 46202, USA
}

Correspondence should be addressed to Randall T. Loder, rloder@iupui.edu

Received 15 May 2011; Accepted 20 June 2011

Academic Editor: S. García-Mata

Copyright ( 2011 R. T. Loder and E. N. Skopelja. This is an open access article distributed under the Creative Commons Attribution License, which permits unrestricted use, distribution, and reproduction in any medium, provided the original work is properly cited.

\begin{abstract}
The etiology of Legg-Calvé-Perthes' disease (LCPD) is unknown. There are many insights however from epidemiologic/demographic information. A systematic medical literature review regarding LCPD was performed. The incidence ranges from $0.4 / 100,000$ to $29.0 / 100,000$ children $<15$ years of age. There is significant variability in incidence within racial groups and is frequently higher in lower socioeconomic classes. The typical age at presentation ranges from 4 to 8 years (average 6.5 years), except for children from the Indian subcontinent (average 9.5 years). There is a mild familial component. The children demonstrate impaired growth in height, skeletal age, and birth weight. This impaired growth coincides with an age appropriate reduced somatomedin A activity and decreased levels of IGF. LCPD can be associated with abnormalities in the coagulation cascade, including an increase in factor V Leiden mutation, low levels of protein C and/or S, and decreased antithrombin activity. There is decreased turnover in type I collagen and synthesis of type III collagen, as well as reduced levels of urinary glycosaminoglycans in the active phases of the disorder. Subtle abnormalities in the opposite hip and other minor/major congenital defects are reported. Children with LCPD are active and score abnormally in certain standardized psychological tests.
\end{abstract}

\section{Introduction}

Legg-Calvé-Perthes' disease (LCPD) is an idiopathic osteonecrosis of the proximal capital femoral epiphysis in children. The epiphysis undergoes collapse, resorption, reossification, and eventual healing. The healed hip may range from an essentially normal contoured femoral head (Stulberg I) to one with incongruous incongruity (Stulberg V). As with any pathologic process, LCPD goes through a course of disease denoted by the Waldenström stages, which are synovitic, avascular, fragmentation (collapse), reossification (healing), and healed (residual). The magnitude of epiphyseal involvement is determined by the Catterall class [1], Salter-Thompson group [2], and/or lateral pillar group [3]. The Catterall class is determined on both anteroposterior and frog-lateral radiographs during the stage of maximum fragmentation, the Salter-Thompson group is determined on the frog-lateral radiograph during the avascular/precollapse stage using the subchondral crescent fracture, and the lateral pillar classification is determined on the anteroposterior radiograph during early fragmentation.

\section{Materials and Methods}

There are many epidemiologic and demographic findings in LCPD. A systematic review of LCPD was performed. LCPD has been known by at least 22 different names since its first description in the late 19th and early 20th centuries [4]. Since 1963, the official medical subject heading (MESH) used by the National Library of Medicine is Legg-Perthes' disease, but many other names had been previously used. To ensure capture of all the published literature, older terms were also searched as keywords or keyword phrases. Therefore, the terms used to search for LCPD were arthritis deformans juvenilis, Calve-Perthes disease, coxa plana, femoral head 
necrosis, juvenile chondroepiphysitis, Legg-Calve-Perthes disease, Legg-Perthes disease, Legg's disease, osteochondritis deformans juvenilis, osteochondritis deformans juvenilis coxae, osteochondritis juvenilis, osteochondrosis of capital epiphysis of femur, Perthes disease, and pseudocoxalgia.

The databases searched were PubMed (http://www.ncbi. nlm.nih.gov/pubmed/), Ovid Medline, EMBASE, WorldCat (books and theses) (http://firstsearch.oclc.org/), and IndexCat (Index Catalogue of the Library of the SurgeonGeneral's Office) (http://www.indexcat.nlm.nih.gov/). Exclusion criteria were those manuscripts discussing surgery, therapy, rehabilitation, and any foreign language articles without an English abstract. Individual journals were also searched for articles published prior to 1996 that predate electronic Medline indexing, including Journal of Bone and Joint Surgery (American and British), Clinical Orthopaedics and Related Research, and Acta Orthopaedica Scandinavica. Age groups were limited to those $<18$ years old. Duplicate citations were removed. The dates for the search were 1880 1961 for IndexCat, 1900-2009 for WorldCat, 1948-1965 for OldMedline, and 1950-February 2010 for Ovid Medline.

This search resulted in 1124 unique citations. These 1124 manuscripts were reviewed to find those that discussed any of the topics regarding etiology, epidemiology, demographics, incidence, prevalence, race, gender, family history, genetics, inheritance, age, bone age, weight (either birth weight or normal weight), height, growth, maturation, other anthropometric characteristics, hormone/endocrine, smoking, coagulation, fibrinolysis, congenital anomalies, collagen, immunoglobulin, opposite hip, behavior/psychology, seasonal variation, and infection. Of these 1124 manuscripts, 144 provided ample information and are the contents of this paper.

\section{Results}

3.1. Incidence. The conventional quotation for the incidence of LCPD is the number per 100,000, usually for age $<15$ years. The incidence of LCPD ranges widely, from 0.4 in Eastern India (Vellore-Taluk area) to 29.0 (Table 1) in the Faroe Islands (North Atlantic ocean). Significant variability exists within countries, cities, and ethnic groups. Race is classified using the definitions of Eveleth and Tanner: Caucasians, Africans in Africa and of African ancestry, Asiatics (Amerindians, Hispanics, Indonesian-Malays), IndoMediterraneans (inhabitants of the Near East, North Africa, and Indian subcontinent), and Australian Aborigines and Pacific Island peoples [23].

\subsection{Whites}

3.2.1. British Isles. The incidence ranges from 5.5 in Wessex, England [13], to 15.6 in Liverpool, England [21]. The incidence in 3 different regions of England [13] was 5.5 in the Wessex Health District, 7.6 in the Trent Health District, and 11.1 in the Mersey Health District (including Liverpool) (Figure 1(a)). In Liverpool, the incidence in the inner city was higher (21.1) compared to the surrounding areas (13.1outer Liverpool, 14.6-Knowsley district, 11.9-Sefton district) [21] (Figure 1(b)) implying that the incidence is lower in less populated or more rural areas. However, in southwest Scotland [20], the incidence was higher in less populated areas (17 to 30 ) compared to more populated areas (4.5). In Yorkshire, England, which has a substantial rural population, the average incidence was 6.1 , with large geographical variations unexplainable by differences between urban and rural populations [15]. The East Riding area of Yorkshire, located on the best agricultural land, had no cases [15].

Many authors have noted differences in incidence by social class and/or inner city/urban/rural location. In the seminal epidemiologic study of 310 children in Edinburgh and Glasgow, Scotland [24], there was a higher than expected proportion of children with LCPD in lower socioeconomic classes; the same was noted in Liverpool [25] (Figure 2(a)). The incidence in the Liverpool inner city within the highest socially deprived area was 31.7 and 10.3 for the lowest; in the outer city the incidence was 21.8 within the highest socially deprived area and 7.4 for the lowest [21] (Figure 2(b)). In Northern Ireland [19], the highest incidence is in the most deprived rural location (16.1), over twice that in the least deprived rural location (7.1). In Southwest Scotland [20], the incidence was 33.6 in the most deprived areas and 7.8 in the least deprived areas; the 33.6 incidence is the highest found to date in any series/publications. However, in Glasgow, there was no association of LCPD incidence and social class [26]. In general, the incidence of LCPD in the British Isles is higher in lower socioeconomic classes and variable regarding rural/urban location (Figure 2(b)).

3.2.2. Scandinavia. The incidence is 8.5 in Uppsala, Sweden [16], and 9.2 in Norway [17]. Within Norway, similar to the British Isles, there is significant variability; the lowest incidence in the north (5.4) and the highest in the center and west (10.8 and 11.3).

3.2.3. North America. In British Columbia [12], the incidence was 5.10 and, in Massachusetts, [14] 5.7.

3.2.4. Africa. In Eastern Cape, South Africa [6], the incidence in Whites is 10.8; in the urban areas (Port Elizabeth and Uitenhage), it is $\sim 2$ times greater than in rural areas. This urban-rural dichotomy was noted overall (3.85 versus 1.1 ) and when separated by race ( 12.6 versus 6.0 for Whites, 2.2 versus 1.4 for mixed African-White, and 0.7 versus 0.28 for Africans).

3.3. Indo-Malays. In Japan [7], the incidence was 0.90 . In Bradford, England, the incidence was 4.6 in Caucasian children and 0.63 in Indo-Malay children [27]. In Korea [9], the incidence was 3.8 and lower in the greater Gwanju metropolitan areas compared to the rural Chonnam province (3.2 versus 4.3 ). 
TABLE 1: Incidence of Legg-Calvé-Perthes' disease* .

\begin{tabular}{|c|c|c|c|c|c|c|}
\hline Study & Year & City, country & Region & Ethnicity & No Pts & Incid \\
\hline Joseph et al. [5] & 1988 & Vellore, India & Asia & Indo-Med (Indian) & 4 & 0.4 \\
\hline Purry [6] & 1982 & Eastern Cape, South Africa & Africa & Black & 6 & 0.45 \\
\hline Kim et al. [7] & 2006 & Japan & Asia & Indo-Malay (Japanese) & 711 & 0.9 \\
\hline Purry [6] & 1982 & Eastern Cape, South Africa & Africa & Mixed & 11 & 1.73 \\
\hline Ebong [8] & 1977 & Nigeria & Africa & Black & 10 & 1.8 \\
\hline Rowe et al. [9] & 2005 & Chonnam, Korea & Asia & Indo-Malay (Korean) & 84 & 3.8 \\
\hline Joseph et al. [5] & 1988 & Udupi, India & Asia & Indo-Med (Indian) & 138 & 4.4 \\
\hline Wijesekera [10] & 1984 & Kurunegala, Sri Lanka (Ceylon) & Asia & Indo-Med (Indian) & 76 & 3.96 \\
\hline Thompson and Leong [11] & 1978 & Hong Kong & Asia & Indo-Malay (Chinese) & 32 & 4.5 \\
\hline Gray et al. [12] & 1972 & British Columbia, Canada & North America & White & 379 & 5.1 \\
\hline Barker et al. [13] & 1978 & Wessex, England & British Isles & White & 34 & 5.5 \\
\hline Molloy and MacMahon [14] & 1966 & Massachusetts & North America & White $^{\dagger}$ & 86 & 5.7 \\
\hline Hall and Barker [15] & 1989 & Yorkshire, England & British Isles & White & 101 & 6.1 \\
\hline Barker et al. [13] & 1978 & Trent, England & British Isles & White & 78 & 7.6 \\
\hline Moberg and Rehnberg [16] & 1964 & Zealand, Denmark & Scandinavia & White & NA & 8.0 \\
\hline Moberg and Rehnberg [16] & 1992 & Uppsala, Sweden & Scandinavia & White & 51 & 8.5 \\
\hline Moberg and Rehnberg [16] & 1964 & Jutland, Denmark & Scandinavia & White & NA & 9.0 \\
\hline Wiig et al. [17] & 2006 & Norway & Scandinavia & White & 425 & 9.2 \\
\hline Purry [6] & 1982 & Easter Cape, South Africa & Africa & White & 38 & 10.8 \\
\hline Margetts et al. [18] & 2001 & Liverpool, England & British Isles & White & 122 & 11.1 \\
\hline Barker et al. [13] & 1978 & Mersey, England & British Isles & White & 68 & 11.1 \\
\hline Kealey et al. [19] & 2000 & Northern Ireland & British Isles & White & 313 & 11.6 \\
\hline Pillai et al. [20] & 2005 & Dumfries, Scotland & British Isles & White & 40 & 15.4 \\
\hline Hall et al. [21] & 1983 & Liverpool, England & British Isles & White & 157 & 15.6 \\
\hline Niclasen [22] & 1974 & Faroe Islands, Denmark & Scandinavia & White & 43 & 29.0 \\
\hline
\end{tabular}

* (per 100,000 children $<15$ yrs old).

${ }^{\dagger}$ one of the 86 children was African.

NA: not available.

\subsection{Indo-Mediterraneans}

3.4.1. India/Sri Lanka. There is a 10 -fold variability in incidence in India; 0.4 in the east (Vellore Taluk) [5] to 4.4 in the west (Udupi Taluk). In Sri Lanka (Kurunegala district) the incidence is 3.96 [10], and all 76 children with LCPD were from lower income groups [10].

3.5. Africans. True LCPD (excluding sickle cell hemoglobinopathy) is extremely rare in Africans. In Eastern Cape, South Africa [6], the incidence is 0.45 and rises to 1.73 in children of mixed African/Caucasian ancestry. The incidence is 1.8 in Nigeria [8]. In Togo, there were 22 cases of LCPD in 29620 children attending two Togolese hospitals over a 7year period, indicating the rarity of the disorder. One of 86 children in Massachusetts [14] was African, and two of the 188 children in Connecticut was African [28].

\subsection{Other Demographics (Age, Gender, Laterality, Family History)}

3.6.1. Age, Gender, Laterality, LCPD Severity. The average age is 6.5 years, with a typical age range of 4 to 8 years (Table 2). The average age for Indian children is 9.5 years, for Nigerian children 10.3 years, and for all others 6.3 years. LCPD is more common in boys $(81.4 \%)$ than girls $(18.6 \%)$ and mostly unilateral $(89.2 \%)$. Right and left hip involvement is similar (46.5\% and 53.5\%). In 1638 hips (Table 3), 112 (6.8\%) were Catterall class I, 295 (18.0\%) class II, 710 (43.3\%) class III, and $521(31.8 \%)$ class IV. In 1671 hips, 236 (14.1\%) were lateral pillar group A, $971(58.1 \%) \mathrm{B}$ and B/C border, and 464 (27.8\%) C.

3.6.2. Family History/Genetics. A positive family history has been noted by many [7, 24, 27, 28, 37-41]. Quoted percentages are $4.5 \%$ [7], 7\% [28], and 8\% [27]. There are also reports in siblings $[42,43]$. The recurrence risk was $2.6 \%$ for siblings and offspring in a review of the family histories of 842 English children with LCPD [44], arguing for a multifactorial inheritance pattern. The proportion of the 842 children having a 1st degree relative with LCPD was $1.6 \%$, a 2 nd degree relative $0.27 \%$, and a 3 rd degree relative $0.27 \%$; all higher than the average English incidence. In South Wales [45], the risk of LCPD in siblings was under 1\% and of an affected parent 3\%. There are several case reports of LCPD transmitted through several generations $[40,46]$. In the Faroe Islands [47], an isolated genetic community, an accumulation of both LCPD and developmental dislocation 


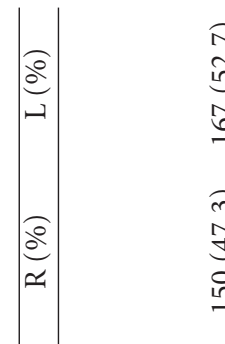

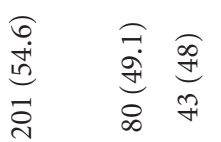

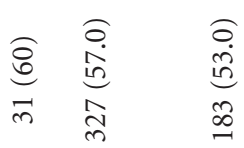

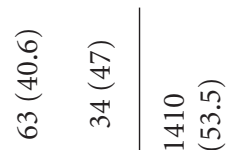

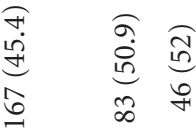

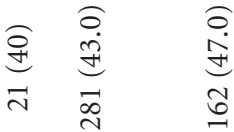

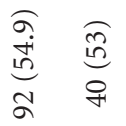
તิ

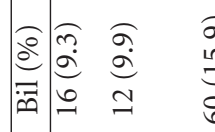

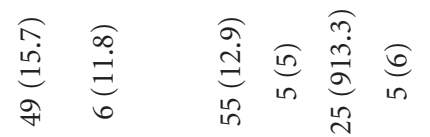

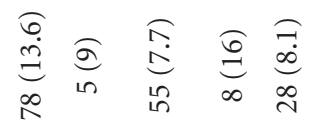

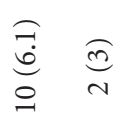
$\overparen{\infty}$
$\stackrel{0}{\Xi}$
a
@)
त̊

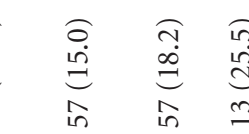

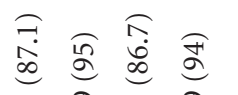

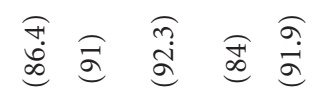

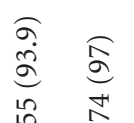
唡
各
के त़่

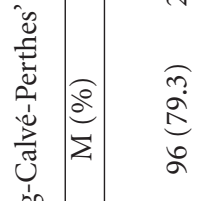

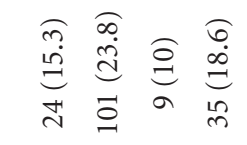

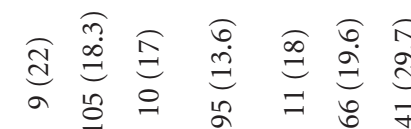

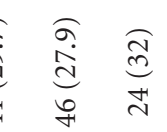

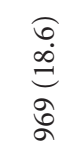

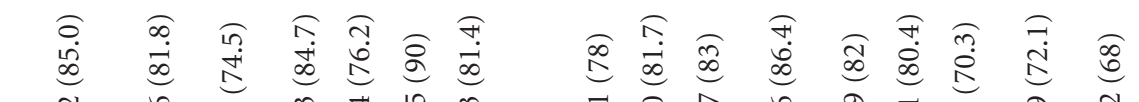

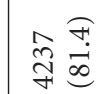

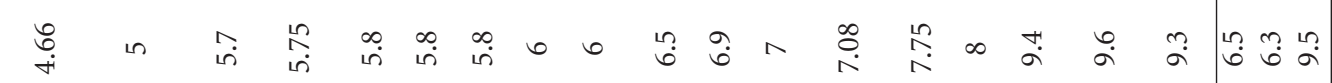

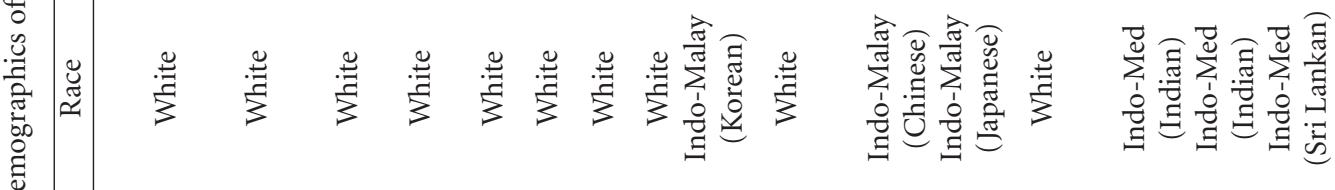

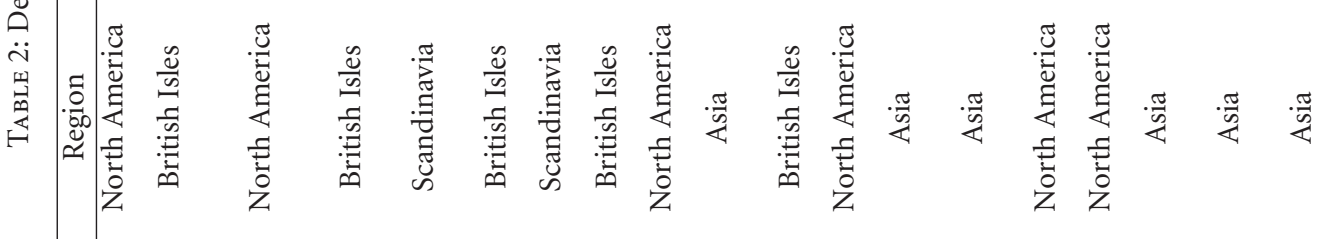

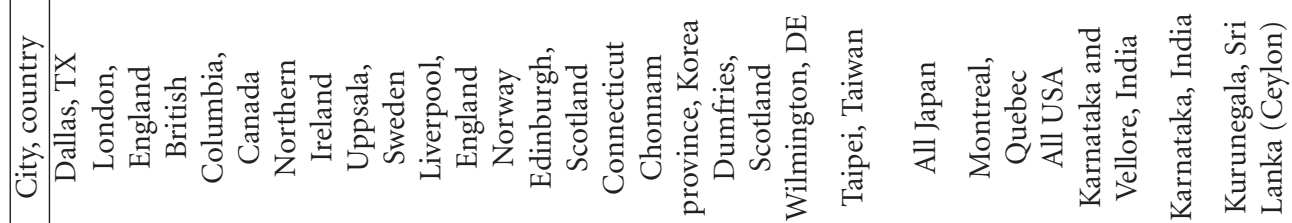
矛兽

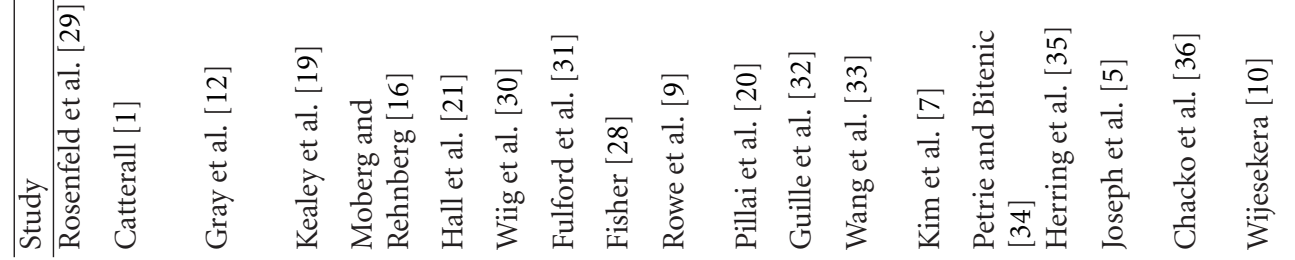




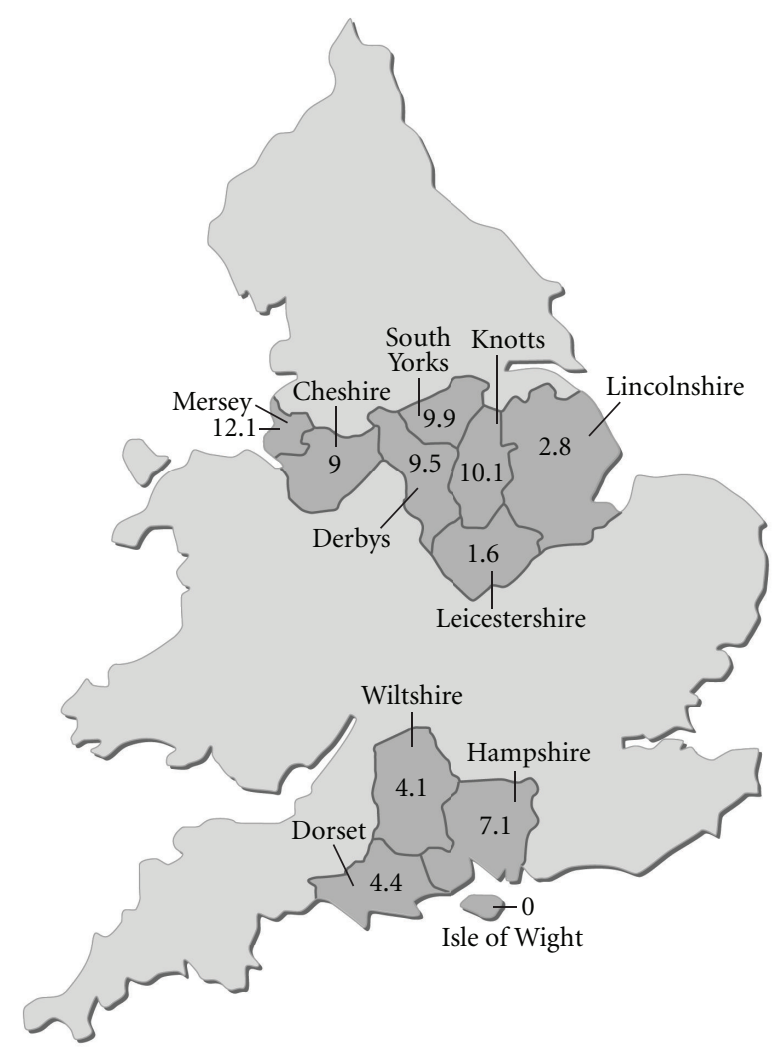

(a)

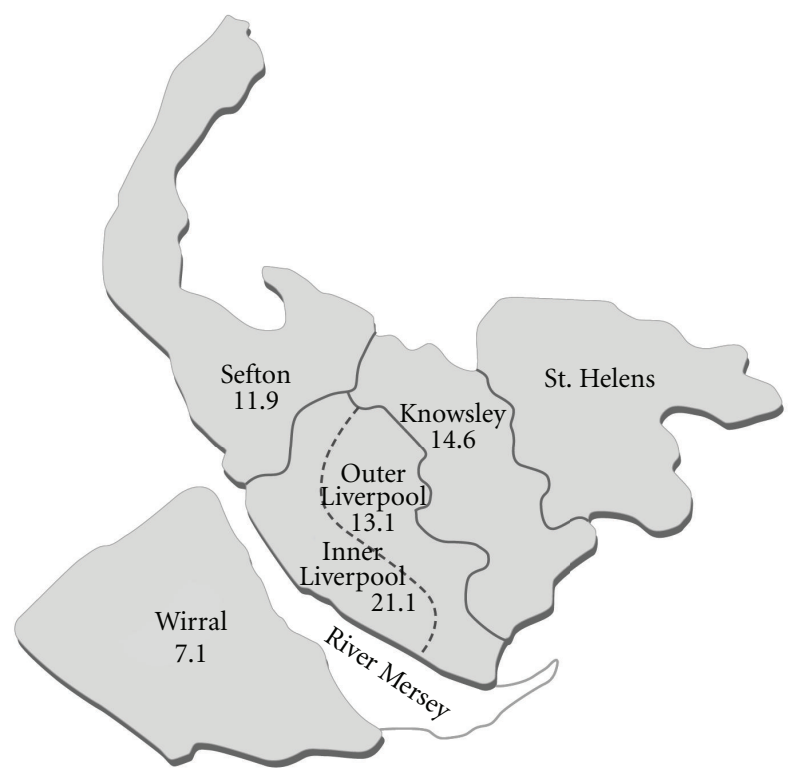

(b)

FIGURE 1: Maps demonstrating various incidences of LCPD in different regions of England. (a) Incidence of LCPD in 1976 per 100,000 children aged 14 years and under in three regions of England. Map of England taken and adapted from the National Policing Improvement Agency, located at http://maps.police.uk/, with permission (Data from [13]). (b) Average yearly incidence of LCPD per 100,000 children aged 14 and under in the Liverpool administrative area. Map of Merseyside area taken and adapted from the National Museums Liverpool located at http://www.liverpoolmuseums.org.uk/maritime/exhibitions/magical/placenames/index.asp, with permission (Data from Hall et al. [21] and Barker et al. [13] (Wirral)).

TABLE 3: Severity of epiphyseal involvement in Legg-Calvé-Perthes' disease.

\begin{tabular}{|c|c|c|c|c|c|c|c|c|c|c|c|}
\hline \multirow{2}{*}{ Study } & \multirow{2}{*}{ Year } & \multirow{2}{*}{ Location } & \multicolumn{4}{|c|}{ Catterall class } & \multicolumn{5}{|c|}{ Lateral pillar group } \\
\hline & & & I & II & III & IV & A & B & $\mathrm{BC}$ & $\mathrm{B}+\mathrm{BC}$ & $\mathrm{C}$ \\
\hline Rosenfeld et al. [29] & 2007 & Dallas, TX & & & & & 7 & 108 & 30 & 138 & 43 \\
\hline Catterall [1] & 1971 & London, England & 31 & 31 & 22 & 13 & & & & & \\
\hline Guille et al. [32] & 1998 & Wilmington, DE & 37 & 120 & 228 & 233 & 155 & 204 & & 204 & 204 \\
\hline Wang et al. [33] & 1990 & Taipei, Taiwan & 0 & 7 & 19 & 21 & & & & & \\
\hline Kim et al. [7] & 2006 & Japan & 30 & 103 & 352 & 210 & 68 & 350 & & 350 & 157 \\
\hline Herring et al. [35] & 2004 & USA & & & & & 6 & 218 & 61 & 279 & 60 \\
\hline Wijesekera [10] & 1984 & Kurunegala, Sri Lanka & 13 & 21 & 33 & 11 & & & & & \\
\hline Chacko et al. [36] & 1986 & Karnataka, India & 1 & 13 & 56 & 33 & & & & & \\
\hline & Total & & 112 & 295 & 710 & 521 & 236 & 880 & 91 & 971 & 464 \\
\hline & Percentage & & 6.8 & 18.0 & 43.3 & 31.8 & 14.1 & 52.7 & 5.4 & 58.1 & 27.8 \\
\hline
\end{tabular}

of the hip was noted in certain families; it remains to be determined if this is genetic, environmental, or both. Others note no significant association with family history $[24,33]$.

There are case reports of LCPD in twins, both monozygotic [48-51] and dizygotic [52], as well as three female 1st degree relatives [53]. These dated studies could not assess for genetic markers, and thus it is unknown if this represents a true genetic pattern or simply the statistical chance of siblings developing the same disease. Wynne-Davies and Gormley [24] described 6 sets of twins with only one of the twins having LCPD. 


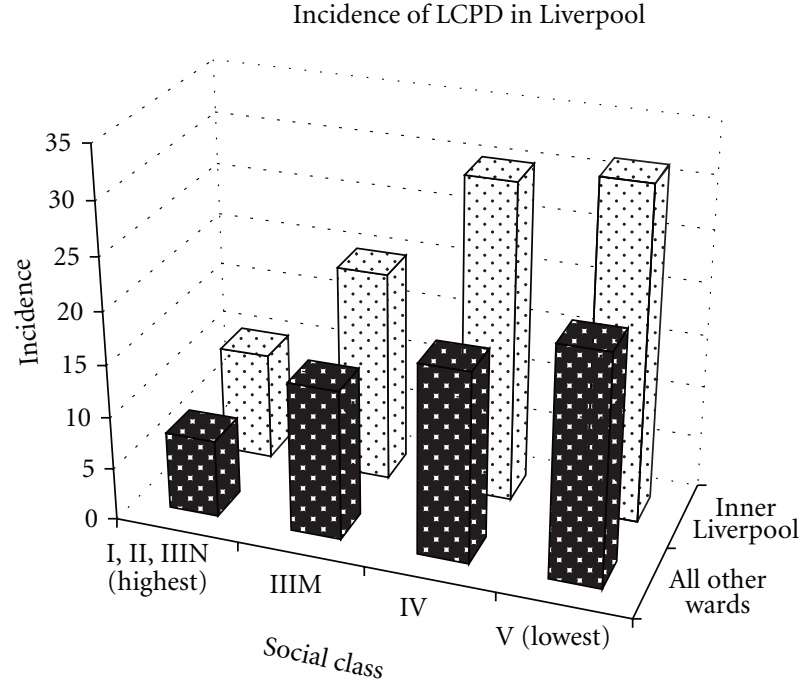

(a)

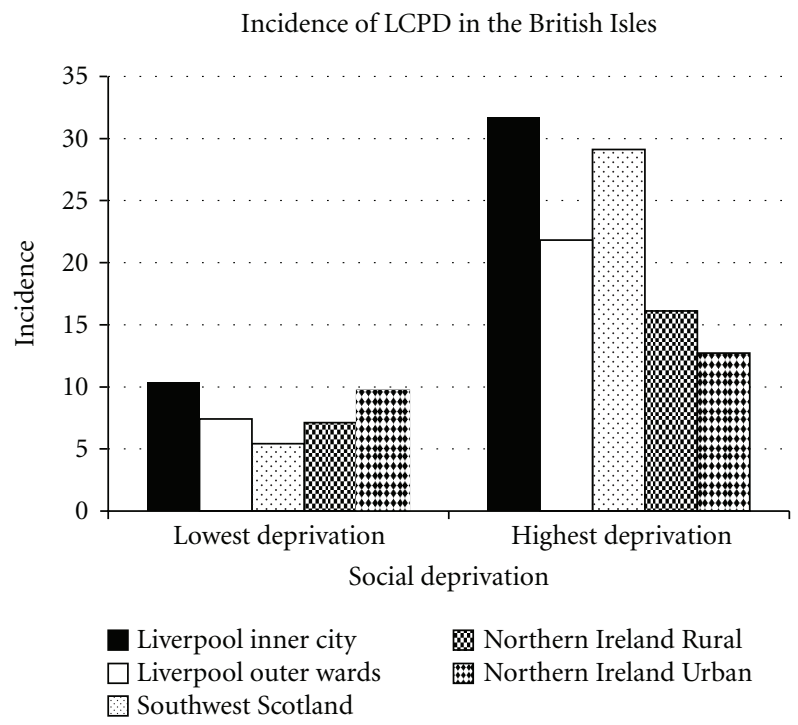

(b)

Figure 2: (a) Incidence of LCPD (100,000 children per year $\leq 14$ years of age) by social class in location in Liverpool (Data from Hall et al. [21]). (b) Composite incidence of LCPD (100,000 children per year $<14$ years of age) by highest and lowest deprivation indices separated by rural and urban locations in the British Isles (Data from Hall et al. [21], Kealey et al. [19], and Pillai et al. [20]).

Several studies show associations with certain HLA types. A positive association was noted with $\operatorname{HLA}_{-} \mathrm{A}_{1}[54,55]$ and HLA-A, HLA-A 10 , and HLA-B 27 [56]. A protective effect was seen with HLA-A $\mathrm{A}_{2}$ and HLA-Cw3; the incidence of LCPD was less in those types [57]. Two studies found no differences in HLA types $[58,59]$. There is no apparent association between $\mathrm{ABO}$ and $\mathrm{Rh}$ blood groups [60].

3.7. Perinatal Factors (Parental Age, Birth Order/Presentation, Birth Weight). Both parents of children with LCPD were older than the normal population (31.7 versus 28.8 years for the fathers, 28.9 versus 26.9 for the mothers) in one study [24], with no differences noted in parental age by others $[28,33,61]$.

LCPD was more frequent in the 3rd born or older children [24] in one study, while others noted no differences [33]. Children with LCPD are more commonly born breech $-10.7 \%$ compared to $2-4 \%$ in the normal population [24]. A lower birth weight was noted in children with LCPD $[62,63] ; 7.1 \mathrm{lbs}$ in 70 children with LCPD and $7.8 \mathrm{lbs}$ in 70 control children without LCPD [62]. In 5 sets of twins, the smaller twin at birth developed the LCPD [63]; the average discordance in birth weight was $13.4 \%$ (range 7.1 to $23.5 \%$ ). Others note no differences in birth weight $[24,33,61]$.

\subsection{Impaired Growth, Anthropometric Differences, and Skeletal Maturation}

3.8.1. Impaired Growth and Anthropometric Differences. Height retardation was noted in 185 Ohio children with LCPD [64], even when accounting for parental height; body weight was average or above average. In Scottish children, a greater proportion of LCPD children have diminished height ( $<10$ th percentile) with no differences for weight [24]. In 76 Sri Lanka children with LCPD, 46\% were below average height at presentation [10]. In 109 Japanese children with LCPD, 97 (89\%) were below the mean in height [65]. Children with LCPD are shorter at birth and remained so during the phases of LCPD and adulthood $[66,67]$; boys were $4.4 \mathrm{~cm}$ shorter and girls $2.5 \mathrm{~cm}$ shorter than their norms [66]. No height or weight differences were found in Irish [68] and Jewish children with LCPD [69].

Skeletal growth is progressively impaired in a caudal direction. Rostral sparing is documented by normal head growth [70] with increasing growth retardation in a caudal direction: biacromial width was less reduced than standing height; forearm and hand showed more impaired growth than the upper arm; the feet showed more impaired growth than the leg. This impaired growth most severely affects the feet $[24,71]$. Growth retardation in LCPD children from rural India [72] is identical to English children.

3.8.2. Skeletal Maturation. Aside from one study in Jewish children with LCPD [69], all others note delayed bone age in LCPD. In 182 children with LCPD, many were <3rd percentile bone age, which was more common in boys than girls [76]. In 125 of 140 (89\%) children with LCPD [28] bone age was delayed. Bone age was at least 3 months less in $83 \%$ of children [67]. This is seen [75] with both the Greulich-Pyle hand-wrist assessment [73] and the Oxford pelvis method [74] of determining bone age (Figure 3 ). The average chronologic age for both boys and girls was 8.2 years; for boys, the average hand-wrist bone age was 7.4 years and average pelvic bone age 5.9 years, and, for girls, the average hand-wrist bone age was 6.9 years and average pelvic bone 7.0 years [75]. Carpal maturation was delayed in 125 children with LCPD; the most severe delay was at 3 to 5 years of age [77]. In a study of 27 girls with LCPD at the time of diagnosis [78], bone age (Tanner Whitehouse 2 method) was delayed 


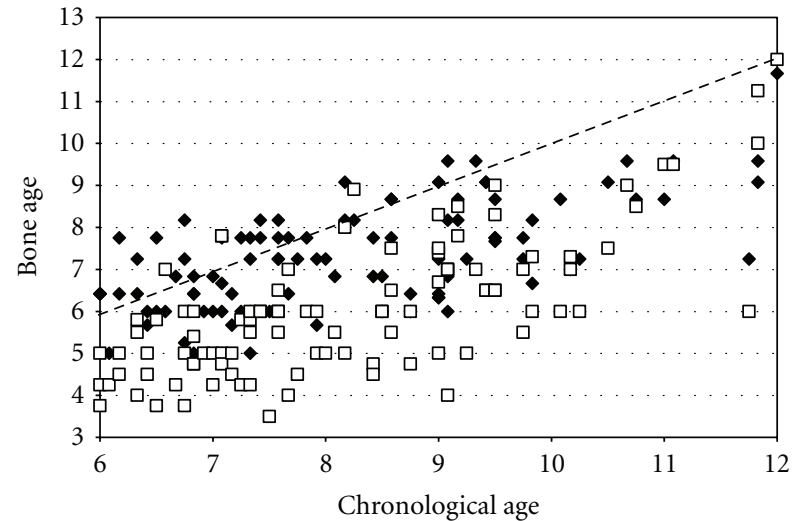

- OX AG

$\square$ GP AG

FIGURE 3: Chronologic age as a function of bone age in 100 children with LCPD. Both the hand-wrist bone of Greulich and Pyle (GP AG) [73] as well as the Oxford pelvic bone age (OX AG) [74] are shown (Data from the study of Loder et al. [75]).

an average of 1.4 years for the radius/ulna and 1.9 years for the carpals. A greater delay in bone age is associated with more severe LCPD [79]. Children with transient synovitis show minimal delay in bone age compared to those with LCPD (7 months versus 23 months) [80].

In non-Caucasians, bone age was delayed 31.8 months in 17 of 25 Formosan (68\%) children with LCPD [33]. In Hong Kong, all Chinese children with LCPD had a bone age lower than the mean [11]. In Korean children, bone age was delayed 10.4 months in boys and 4.6 months in girls [9]. In 21 Japanese LCPD children, delayed bone age was noted in all [65]. In 76 Sri Lankan children, 78\% demonstrated skeletal retardation [10]. In Mexican children (HispanicAmerindian), bone age was delayed 28 months in children with LCPD between the ages of 6-10 years [81].

Skeletal standstill (no increase in bone age with increasing chronologic age) occurs in $\operatorname{LCPD}[75,76]$ and resolves after the LCPD has healed [80].

3.9. Endocrine Dysfunction. Postnatal skeletal development is regulated by growth hormone, whose effects are partly mediated by somatomedins. Somatomedins stimulate cartilage activity resulting in cell proliferation and hypertrophy. In Japan, the incidence of LCPD was 70 in growthhormone-deficient children [82] compared to 0.9 in the normal population [7]. Serum growth hormone response to insulin-induced hypoglycemia is reduced in boys with LCPD compared to those with constitutional short stature [83]. The primary somatomedin responsible for postnatal skeletal maturation is somatomedin $\mathrm{C}$ insulin-like growth factor (IGF-1). Somatomedin deficiency may result in impaired skeletal maturation, a well-known phenomenon in LCPD. Somatomedin A [84] and C [65] deficiency has been noted LCPD. Somatomedin activity normally increases with age in growing children, but this does not occur in children with LCPD $[85,86]$. Plasma levels of IGF-1 were reduced the first
2 years after the diagnosis of LCPD [87], but with normal levels of IGF-binding protein [88]. Low levels of IGF-1 were confirmed by Crofton et al. [89], who also noted abnormal collagen turnover in the acute stages of LCPD. In plasma, nearly all the IGF-1 is bound to specific binding proteins, which for IGF-1 is the IGF-binding protein 3 (IGFBP3). Decreased levels of IGFBP in children with LCPD have been seen but with normal levels of IGF-1 [90]. No abnormalities in IGF-1 or IGFBP concentrations have been encountered by others $[68,83,91,92]$ in children with LCPD.

Early studies $[93,94]$ noted an association with hypothyroidism and LCPD but not seen in more recent studies [68, 83, 95-98]. No abnormalities in adrenal function (cortisol) $[68,83]$ or cholesterol [96] have been noted.

3.10. Smoking, Hypofibrinolysis, and LCPD. Passive smoke exposure during pregnancy has been correlated with LCPD. This was first noted in Massachusetts [62]; maternal smoking while pregnant was present in $63 \%$ of LCPD and $43 \%$ of control cases. This was confirmed in Sweden [99]; maternal smoking during pregnancy increased the odds of developing LCPD in the child by 1.44 if the mother smoked $<10$ cigarettes per day, and by 2.1 when $\geq 10$ cigarettes per day. It was also noted that children with a birth weight $<1500$ gms had a 2.4 times increased risk of developing LCPD.

An increase in LCPD in children exposed to passive smoke after birth has also been noted. In children with LCPD [100], 63.9\% had at least one smoker living in the child's household with a mean of 1.03 smoker years per year of life exposure to smoke; in control children, $39.6 \%$ had at least one smoker living in the child's house with a mean of 0.48 smoker years per year of life exposure to smoke. No association was noted between lower income and LCPD. This association with passive smoke exposure was corroborated in Spain [101], where 79\% of LCPD children were passive smokers compared to $43 \%$ of controls. The odds ratio for a child, after controlling for age and gender, of developing LCPD when exposed to passive smoke was 5.3 (95\% CI 2.9-9.7). There were no associations between passive smoking and age of child, Catterall class, or final Stulberg result. In another study of 39 children with LCPD [102], 24 had exposure to second hand smoke, some even in utero (17 of the 24). Of the children with LCPD and smoke exposure, $48 \%$ had low stimulated tissue plasminogen activator activity, compared to only $7 \%$ of the children without smoke exposure. In Georgia [103], children exposed to passive smoke were 5.6 (95\% CI 2.0-12.0) times more likely to develop LCPD than those not exposed. This was strongly associated with a polymorphism in the $\beta$-fibrinogen gene G-455-A, which results in increased fibrinogen levels, thus leads to thrombotic/coagulation abnormalities in children with LCPD (Figure 4).

Factor V Leiden mutation discovered in Leiden, Netherlands [104], results in production of factor $\mathrm{V}$ that cannot be inactivated by activated protein $\mathrm{C}$. This leads to a persistence of circulating activated factor $\mathrm{V}$ with continued activation of the coagulation cascade and a hypercoagulable state. Families with LCPD and factor V Leiden mutations have 


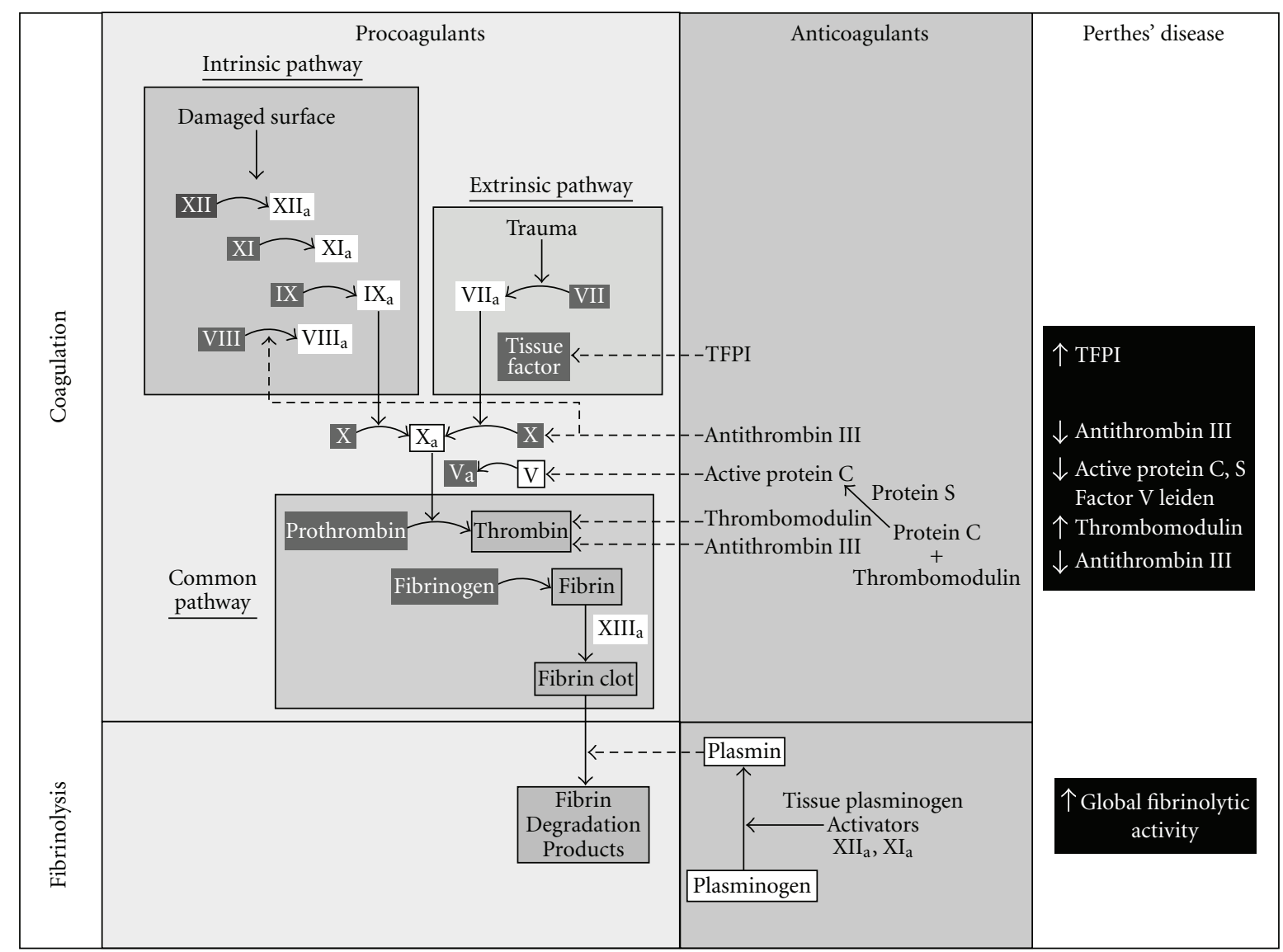

FIGURE 4: The coagulation and fibrinolytic cascade as it relates to children with LCPD. The abnormalities in this cascade in children with LCPD are shown in the far right column. TFPI: tissue factor pathway inhibitor.

been described $[105,106]$. In nonfamilial LCPD, a factor $\mathrm{V}$ Leiden mutation has been noted by many; $12.5 \%$ [107] and $10.6 \%$ in children with LCPD [108] in studies without controls. In studies with controls, these values are $30 \%$ in LCPD and $1.87 \%$ in controls [109], $11 \%$ in LCPD and $4 \%$ in controls [110], 9\% in LCPD and 5\% in controls [111], and $4.9 \%$ in LCPD and $0.7 \%$ in controls [112]. Children with the most severe LCPD (Catterall IV) were homozygous for factor V Leiden mutation [108]. High levels of anticardiolipin antibodies (26\% versus $11 \%$ ) have also been noted [110]. The OR of developing LCPD with factor $\mathrm{V}$ Leiden mutation in two studies are 22.5 [109] and 3.3 [113]; the OR of developing LCPD with $\geq$ abnormalities in factor $\mathrm{V}$ or anticardiolipin antibody is 3.29 [110].

Other coagulation abnormalities exist in LCPD. Thrombophilia and hypofibrinolysis were noted in 8 children [114] in 1994. A subsequent investigation noted that $75 \%$ of 44 children with LCPD had coagulation abnormalities [115]; thrombophilia (a deficiency in antithrombotic factor $\mathrm{C}$ or $\mathrm{S}$, with an increased tendency towards thrombosis) in 23 children; increased lipoprotien(a) (a thrombogenic lipoprotein associated with osteonecrosis in adults) in 7 children; hypofibrinolysis (reduced ability to lyse clots) in 3 children. In another study, only 14 of 64 children $(22.5 \%)$ with LCPD had entirely normal coagulation measures [107] with resistance to activated protein $\mathrm{C}$ the most common abnormality (23 of 64). A 3.8 times increased risk for LCPD with low levels of protein $\mathrm{C}$ has been found [111]. Protein C activity is also lower in LCPD $[116,117]$. Both protein C and antithrombin activities were lower in LCPD than controls [117]; a family history of hereditary thrombophilia was higher in LCPD than controls. LCPD was increased 2.8 times with protein $\mathrm{S}$ deficiency and 7.5 times with elevated factor VIII levels [113]. Others note no coagulation abnormalities in LCPD [116, 118-127].

Another fact supporting a hypercoagulable state in LCPD is tissue factor pathway inhibitor (TFPI). TFPI is an important natural anticoagulant molecule that downregulates the tissue factor dependent coagulation pathway. A deficiency leads to a prothrombotic state, and over expression may be a protective mechanism against ongoing local microvascular events. TFPI concentrations in children with LCPD were significantly higher $(56.8 \mathrm{ng} / \mathrm{mL})$ compared to controls $(37.3 \mathrm{ng} / \mathrm{mL})$ [128]. This is interpreted as a physiologic response to a hypercoagulable state; an increased TFPI is natural anticoagulation. Increased blood viscosity in LCPD is reported [129]; thus vascular occlusion may simply be due to fluid mechanic properties [129].

After thrombosis, the body attempts to lyse the clot. Fibrinolysis is mediated in part by thrombomodulin, an endothelial cell membrane-associated glycoprotein which functions in activation of the anticoagulant systems. In 


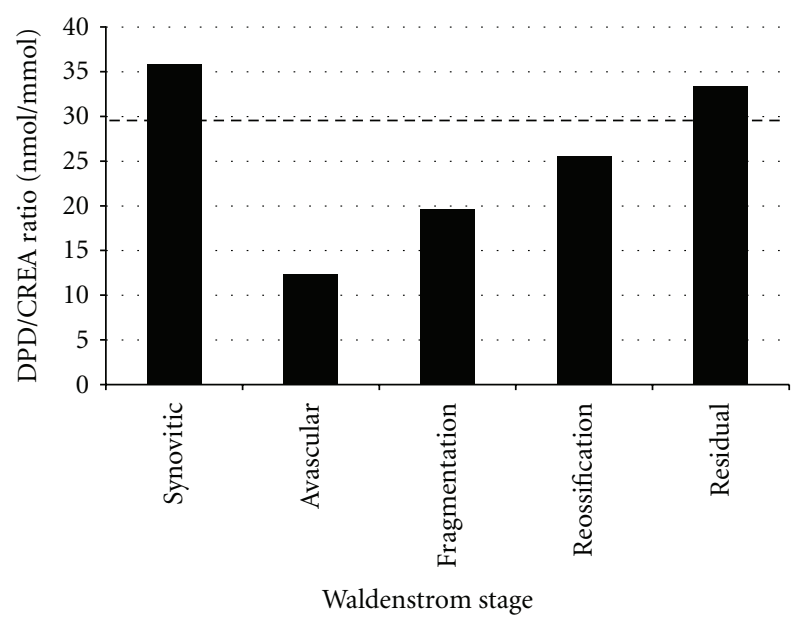

FIGURE 5: Urinary DPD/CREA (urinary deoxypyridinoline/creatinine ratio) in children with LCPD in different Waldenström stages. The control level is denoted by the hatched line. DPD is a degradation product of type I collagen; a decrease in its urinary excretion indicates a decrease in bone turnover. Thus, there is decreased bone turnover in children with LCPD during the avascular and fragmentation phases of the disease (Data from Westhoff et al. [131]).

LCPD, thrombomodulin and global fibrinolytic activity are elevated [130]. This is interpreted as a compensatory reaction to the thrombosis in LCPD.

\subsection{Other Associations with LCPD}

3.11.1. Collagen Metabolism/Genetics and Bone Turnover. Type I collagen is found almost exclusively in bone and calcifying tissues. Markers of type I collagen degradation are urinary deoxypyridinoline (DPD) and type I collagen telopeptide (ICTP). ICTP is higher in children with LCPD compared to controls [89], indicating an increase in type I collagen degradation. The median urinary DPD/creatinine ratio in children with LCPD is reduced during the fragmentation stage and returns to normal (if not slightly higher) in the healed stage [131] (Figure 5). The DPD/creatinine decrease is greater with more severe LCPD (egg lateral pillar C > lateral pillar B). These findings support a systemic etiology in LCPD.

A marker of type III collagen synthesis is the procollagen type III N-terminal propeptide (P3NP). Type III collagen synthesis is reduced at diagnosis in children with LCPD as demonstrated by very low levels of P3NP. However, there were no controls, and the differences in children with LCPD compared to otherwise normal children in the same geographic/ethnic/socioeconomic situation are not known.

A recurrent mutation in type II collagen (cartilage collagen) in a Japanese family with LCPD [38] has been noted. This mutation amino acid change (p.G1170S) perturbs the Gly-X-Y triple-helix of type II collagen. Similar findings were noted in a Chinese family where a p.Gly1170S mutation of COL2A1 resulted in premature hip osteoarthritis, avascular necrosis of the femoral head, or LCPD, depending upon the age at onset [39]. In a cohort of nonfamilial children with LCPD, no mutations in the COL2A1 gene were found [124].

3.11.2. Articular Cartilage Markers. Glycosaminoglycans (GAGs) are chains of repetitive disaccharide units linked with proteins in the cartilaginous extracellular matrix to form proteoglycans. Upon cartilage degradation, GAGs are eliminated by the kidneys. Elevated urinary GAG levels indicate increased articular cartilage degradation. Decreased levels of urinary GAGs in children with LCPD compared to normal children or those with transient synovitis have been noted [132]. This can be interpreted as either increased preservation of the GAGs within the hip or a decrease in the quantity of synovial fluid. Increased levels of proteoglycan fragments and stromelysin in the synovial fluid of children with LCPD have been noted, consistent with a synovitis [133].

3.11.3. The Opposite Hip in Unilateral LCPD. In a review of the radiographs of 153 children with unilateral LCPD [134], 48.4\% demonstrated irregularity of the epiphyseal surface, flattening, or dimpling of the opposite "normal hip." In most instances (37\%), they were present in the initial radiograph. Similar changes were noted in only $10.4 \%$ of a control group of 153 age and gender-matched children using intravenous urograms. This was interpreted as the capital femoral epiphysis in the young child being very vulnerable to stress; the minimal contour irregularities in the "normal hip" represent one end of the spectrum and frank LCPD, the other as the stress response of the capital femoral epiphysis. Another study confirmed that the "unaffected" hip in LCPD demonstrates anterior and lateral flattening perhaps indicating a constitutional abnormality [135]. In a third study, $15 \%$ of the opposite "normal" hips demonstrated physeal changes, especially decalcification below the physis [136]. The initial radiographs of 125 Japanese children with unilateral LCPD demonstrate delayed ossification of the opposite epiphysis as seen by diminished epiphyseal height [137].

3.11.4. Behavioral/Psychological Issues. Children with LCPD are extremely busy and active. An early study ( $\mathrm{PhD}$ thesis) discovered that children with LCPD demonstrated a motorexpressive personality, an active approach to life and had higher psychosomatic and visceral complaints [138]. A later study [139] reviewed the behavioral characteristics of 24 children with LCPD; $33 \%$ of children with LCPD had abnormally high scores in standard psychological child behavioral questionnaires for profiles associated with attention deficit hyperactivity disorder, greater than the $3-5 \%$ of age matched children. Certain epidemiologic characteristics of LCPD (gender, socioeconomic status, geographic location, and associated congenital anomalies) are also similar characteristics of attention deficit hyperactivity disorder. These findings were confirmed in a recent study of 19 children with LCPD [92]; 8 of 12 school-aged children had negative scores in neuropsychological tests and 5 of the 8 had learning difficulties at school. 
3.11.5. Miscellaneous Findings. An increase in both major and minor congenital defects in children with LCPD is known [61]. These include anomalies of the genitourinary tract and inguinal region [140] and spina bifida occulta $[10,141,142]$. Sacral inclination, decreased lumbar lordosis, and an overall more negative spinal balance with vertebral end plate anomalies have been recently described in the spine of LCPD patients [143].

Low blood manganese levels were noted in children with LCPD in Liverpool [144], but refuted by others [145]. An increase in IgG and IgM, but not IgA serum immunoglobulin levels in LCPD, are described [146], suggesting that immunological mechanisms may mediate certain changes in LCPD. Rubella antibody titers are higher in both mothers and affected children with LCPD [147].

\section{Conclusion and Unifying Possibilities}

Can these epidemiologic and demographic findings be unified? There clearly is disharmony between cartilage and bone and growth in LCPD as evidenced by progressive caudal growth impairment and delays in skeletal maturation, both involving the wrist and the pelvis. The insult on skeletal maturation appears to occur early in life, perhaps even prenatally, since there is an increased frequency of minor congenital malformations in children with LCPD. These delays in maturation (both anthropometric and skeletal age) can be due to a combination of familial and environmental circumstances (lower socioeconomic class with malnutrition [148], underlying genetic/collagen defects, or some other unknown entity). The delay in skeletal ossification results in a weaker skeleton that is more susceptible to trauma. A highly active child incurs more skeletal injuries; this microtrauma in a biologically susceptible weaker skeleton creates microfractures in the proximal femoral epiphysis and metaphysis. A hypercoagulable state, due to underlying abnormalities in the clotting mechanisms and/or exposure to passive smoke, results in increased thrombosis in the proximal femur after microfractures with subsequent necrosis of the capital femoral epiphysis and the development of LCPD.

\section{Conflict of Interests}

The author's otherwise have no financial interests with any other organizations or bodies.

\section{Disclosure}

As a systematic literature review, Institutional Review Board approval is not applicable. This was the 2 nd of three presentations on the epidemiology and demographics of Pediatric Hip Disorders given at the AO North American Symposium on Surgical Preservation of the Hip, Squaw Valley, California, January 2009.

\section{Acknowledgment}

This study was supported in part by the Garceau Professorship Endowment, Department of Orthopaedic Surgery,
Indiana University School of Medicine, and the George Rapp Pediatric Orthopaedic Research Endowment, Riley Children's Foundation, Riley Children's Hospital, Indianapolis, Indiana.

\section{References}

[1] A. Catterall, "The natural history of Perthes' disease," Journal of Bone and Joint Surgery. British, vol. 53, no. 1, pp. 37-53, 1971.

[2] R. B. Salter and G. H. Thompson, "Legg-Calve-Perthes disease. The prognostic significance of the subchondral fracture and a two-group classification of the femoral head involvement," Journal of Bone and Joint Surgery. American, vol. 66, no. 4, pp. 479-489, 1984.

[3] J. A. Herring, J. B. Neustadt, J. J. Williams, J. S. Early, and R. H. Browne, "The lateral pillar classification of Legg-CalvePerthes disease," Journal of Pediatric Orthopaedics, vol. 12, no. 2, pp. 143-150, 1992.

[4] A. B. Nevelos, "Perthes' disease: the family tree," Clinical Orthopaedics and Related Research, vol. 209, pp. 13-22, 1986.

[5] B. Joseph, V. Chacko, B. S. Rao, and A. J. Hall, "The epidemiology of Perthes' disease in south India," International Journal of Epidemiology, vol. 17, no. 3, pp. 603-607, 1988.

[6] N. A. Purry, "The incidence of Perthes' disease in three population groups in the Eastern Cape region of South Africa," Journal of Bone and Joint Surgery. British, vol. 64, no. 3, pp. 286-288, 1982.

[7] W. C. Kim, K. Hiroshima, and T. Imaeda, "Multicenter study for Legg-Calvé-Perthes disease in Japan," Journal of Orthopaedic Science, vol. 11, no. 4, pp. 333-341, 2006.

[8] W. W. Ebong, "Legg Calve Perthes disease in Nigerians," International Surgery, vol. 62, no. 4, pp. 217-218, 1977.

[9] S. M. Rowe, S. T. Jung, K. B. Lee, B. H. Bae, S. Y. Cheon, and K. D. Kang, "The incidence of Perthes' disease in Korea. A focus on differences among races," Journal of Bone and Joint Surgery. British, vol. 87, no. 12, pp. 1666-1668, 2005.

[10] C. Wijesekera, "Perthes' disease in Kurunegala," The Ceylon Medical Journal, vol. 29, no. 2, pp. 65-83, 1984.

[11] A. G. Thompson and J. C. Y. Leong, "Legg-Calve-Perthes' disease in Southern Chinese children," Journal of the Western Pacific Orthopaedic Association, vol. 15, no. 1, pp. 63-70, 1978.

[12] I. M. Gray, R. B. Lowry, and D. H. Renwick, "Incidence and genetics of Legg-Perthes disease (osteochondritis deformans) in British Columbia: evidence of polygenic determination," Journal of Medical Genetics, vol. 9, no. 2, pp. 197-202, 1972.

[13] D. J. P. Barker, E. Dixon, and J. F. Taylor, "Perthes' disease of the hip in three regions of England," Journal of Bone and Joint Surgery. British, vol. 60, no. 4, pp. 478-480, 1978.

[14] M. K. Molloy and B. MacMahon, "Incidence of Legg-Perthes disease (osteochondritis deformans)," New England Journal of Medicine, vol. 275, no. 18, pp. 988-990, 1966.

[15] A. J. Hall and D. J. P. Barker, "Perthes' disease in Yorkshire," Journal of Bone and Joint Surgery. British, vol. 71, no. 2, pp. 229-233, 1989.

[16] A. Moberg and L. Rehnberg, "Incidence of Perthes' disease in Uppsala, Sweden," Acta Orthopaedica Scandinavica, vol. 63, no. 2, pp. 157-158, 1992.

[17] O. Wiig, T. Terjesen, S. Svenningsen, and S. A. Lie, "The epidemiology and aetiology of Perthes' disease in Norway," Journal of Bone and Joint Surgery. British, vol. 88, no. 9, pp. 1217-1223, 2006. 
[18] B. M. Margetts, C. A. Perry, J. F. Taylor, and P. H. Dangerfield, "The incidence and distribution of Legg-Calvé-Perthes' disease in Liverpool, 1982-95," Archives of Disease in Childhood, vol. 84, no. 4, pp. 351-354, 2001.

[19] W. D. C. Kealey, A. J. Moore, S. Cook, and A. P. Cosgrove, "Deprivation, urbanization and Perthes' disease in Northern Ireland," Journal of Bone and Joint Surgery. British, vol. 82, no. 2, pp. 167-171, 2000.

[20] A. Pillai, S. Atiya, and P. S. Costigan, "The incidence of Perthes' disease in Southwest Scotland," Journal of Bone and Joint Surgery. British, vol. 87, no. 11, pp. 1531-1535, 2005.

[21] A. J. Hall, D. J. P. Barker, P. H. Dangerfield, and J. F. Taylor, "Perthes' disease of the hip in Liverpool," British Medical Journal, vol. 287, no. 6407, pp. 1757-1759, 1983.

[22] S. D. Niclasen, "Incidence of Legg-Calve-Perthes' disease in the Faroe Islands," Annales Societatis Scientiarum Faroensis, vol. 22, pp. 9-65, 1974.

[23] P. B. Eveleth and J. M. Tanner, Worldwide Variation in Human Growth, Cambridge University Press, Cambridge, UK, 2nd edition, 1990.

[24] R. Wynne-Davies and J. Gormley, “The aetiology of Perthes' disease: genetic, epidemiological and growth factors in 310 Edinburgh and Glasgow patients," Journal of Bone and Joint Surgery. British, vol. 60, no. 1, pp. 6-14, 1978.

[25] D. J. P. Barker and A. J. Hall, "The epidemiology of Perthes' disease," Clinical Orthopaedics and Related Research, vol. 209, pp. 89-94, 1986.

[26] S. Sharma, M. Sibinski, and D. A. Sherlock, "A profile of Perthes' disease in Greater Glasgow. Is there an association with deprivation?" Journal of Bone and Joint Surgery. British, vol. 87, no. 11, pp. 1536-1540, 2005.

[27] A. A. Faraj and A. B. Nevelos, "Ethnic factors in perthes disease: a retrospective study among white and Asian population living in the same environment," Acta Orthopaedica Belgica, vol. 66, no. 3, pp. 255-258, 2000.

[28] R. L. Fisher, "An epidemiological study of Legg-Perthes disease," Journal of Bone and Joint Surgery. American, vol. 54, no. 4, pp. 769-778, 1972.

[29] S. B. Rosenfeld, J. A. Herring, and J. C. Chao, "Legg-CalvéPerthes disease: a review of cases with onset before six years of age," Journal of Bone and Joint Surgery. American, vol. 89, no. 12, pp. 2712-2722, 2007.

[30] O. Wiig, T. Terjesen, and S. Svenningsen, "Prognostic factors and outcome of treatment in Perthes' disease: a prospective study of 368 patients with five-year follow-up," Journal of Bone and Joint Surgery. British, vol. 90, no. 10, pp. 1364-1371, 2008.

[31] G. E. Fulford, P. G. Lunn, and M. F. Macnicol, "A prospective study of nonoperative and operative management for Perthes' disease," Journal of Pediatric Orthopaedics, vol. 13, no. 3, pp. 281-285, 1993.

[32] J. T. Guille, G. E. Lipton, G. Szöke, J. R. Bowen, H. T. Harcke, and J. J. Glutting, "Legg-Calve-Perthes disease in girls. A comparison of the results with those seen in boys," Journal of Bone and Joint Surgery. American, vol. 80, no. 9, pp. 1256$1263,1998$.

[33] N. H. Wang, F. T. Lee, L. S. Chin, and W. H. Lo, "Legg-CalvePerthes disease: clinical analysis of 57 cases," Journal of the Formosan Medical Association, vol. 89, no. 9, pp. 764-771, 1990.

[34] J. G. Petrie and I. Bitenc, "The abduction weight-bearing treatment in Legg-Perthes' disease," Journal of Bone and Joint Surgery. British, vol. 53, no. 1, pp. 54-62, 1971.
[35] J. A. Herring, T. K. Hui, and R. Browne, "Legg-Calvé-Perthes disease. Part II: prospective multicenter study of the effect of treatment on outcome," Journal of Bone and Joint Surgery. American, vol. 86, no. 10, pp. 2121-2134, 2004.

[36] V. Chacko, B. Joseph, and B. Seetharam, "Perthes' disease in South India," Clinical Orthopaedics and Related Research, vol. 209, pp. 95-99, 1986.

[37] M. O'Sullivan, S. K. O’Rourke, and P. MacAuley, "LeggCalve-Perthes disease in a family: genetic or environmental," Clinical Orthopaedics and Related Research, vol. 199, pp. 179181, 1985.

[38] Y. Miyamoto, T. Matsuda, H. Kitoh et al., "A recurrent mutation in type II collagen gene causes Legg-Calvé-Perthes disease in a Japanese family," Human Genetics, vol. 121, no. 5, pp. 625-629, 2007.

[39] P. Su, R. Li, S. Liu et al., "Age at onset-dependent presentations of premature hip osteoarthritis, avascular necrosis of the femoral head, or legg-calvé-perthes disease in a single family, consequent upon a p.Gly1170Ser mutation of COL2A1," Arthritis and Rheumatism, vol. 58, no. 6, pp. 17011706, 2008.

[40] F. E. Stephens and J. P. Kerby, "Hereditary Legg-CalvePerthes' disease," Journal of Heredity, vol. 37, no. 5, pp. 153$160,1946$.

[41] E. McComas, "Perthes' disease and its occurrence as a familial condition," The Medical Journal of Australia, vol. 2, pp. 584$585,1946$.

[42] H. Burlington, "Legg-Perthes disease in siblings; a report of two cases with simultaneous onset," Pennsylvania Medical Journal, vol. 61, no. 7, pp. 887-888, 1958.

[43] H. W. Tracy, "Coxa plana in siblings," North Carolina Medical Journal, vol. 24, pp. 76-79, 1963.

[44] D. J. Hall, "Genetic aspects of Perthes' disease: a critical review," Clinical Orthopaedics and Related Research, vol. 209, pp. 100-114, 1986.

[45] P. S. Harper, B. J. Brotherton, and D. Cochlin, "Genetic risks in Perthes' disease," Clinical Genetics, vol. 10, no. 3, pp. 178182, 1976.

[46] Z. Wamoscher and A. Farhi, "Hereditary Legg-Calve-Perthes disease," American Journal of Diseases of Children, vol. 106, pp. 97-100, 1963.

[47] S. D. Niclasen, "Family studies of relation between Perthes disease and congenital dislocation of the hip," Journal of Medical Genetics, vol. 15, no. 4, pp. 296-299, 1978.

[48] A. Inglis, "Genetic implications in coxa plana," The Journal of Bone and Joint Surgery. American, vol. 42-A, pp. 711-715, 1960.

[49] N. Giannestras, "Legg-Perthes disease in twins," The Journal of Bone and Joint Surgery. American, vol. 36-A, pp. 149-152, 1954.

[50] A. W. Dunn, "Coxa plana in monozygotic male twins," The Journal of Bone and Joint Surgery. American, vol. 42-A, pp. 178-183, 1960.

[51] L. Söderberg, "Simultaneous occurrence of coxa plana in enzygotic twins," Acta Orthopaedica Scandinavica, vol. 27, pp. 135-140, 1957.

[52] P. S. Derian, "Coxa plana in dizygotic male twins," The Journal of Bone and Joint Surgery. American, vol. 38-A, pp. 901-907, 1956.

[53] J. P. Livesey, S. M. Hay, and M. J. Bell, "Perthes disease affecting three female first-degree relatives," Journal of Pediatric Orthopaedics Part B, vol. 7, no. 3, pp. 230-231, 1998. 
[54] J. Bertrams, P. Schiersmann, and G. Ritgen, "HLA antigens in Perthes' disease," Tissue Antigens, vol. 12, no. 2, pp. 157-158, 1978.

[55] J. Zervas, S. Theordorou, and C. Constantopoulos, "HLA-A1 probable association with Perthes' disease," Tissue Antigens, vol. 20, no. 2, pp. 159-160, 1982.

[56] I. A. E. Halwag, E. M. K. El-Abbasy, S. A. Zaki, and M. A. Abou-Khatwn, "Association between HLA-A and -B and Perthes' disease," Journal of the Medical Research Institute, vol. 12, pp. 89-98, 1991.

[57] C. Dostál, V. Raušer, S. Popelka, E. Ivašková, M. Macurová, and J. Zvárová, "HLA antigens in Perthes disease," Acta Chirurgiae Orthopaedicae et Traumatologiae Cechoslovaca, vol. 54, pp. 324-329, 1987.

[58] S. K. Thompson and J. C. Woodrow, "HLA antigens in Perthes' disease," Journal of Bone and Joint Surgery. British, vol. 63, no. 2, pp. 278-279, 1981.

[59] J. Mach and S. Wegener, "HLA-examinations at Perthes disease," Beitrage zur Orthopadie und Traumatologie, vol. 32, no. 12, pp. 590-592, 1985.

[60] J. M. Cameron and M. M. Izatt, "The ABO and rhesus blood groups in Perthes' disease," Journal of Clinical Pathology, vol. 15, pp. 163-168, 1962.

[61] D. J. Hall, M. H. M. Harrison, and R. G. Burwell, "Congenital abnormalities and Perthes' disease. Clinical evidence that children with Perthes' disease may have a major congenital defect," Journal of Bone and Joint Surgery. British, vol. 61, no. 1, pp. 18-25, 1979.

[62] M. K. Molloy and B. Macmahon, "Birth weight and LeggPerthes disease," Journal of Bone and Joint Surgery. American, vol. 49, no. 3, pp. 498-506, 1967.

[63] K. Lappin, D. Kealey, A. Cosgrove, and K. Graham, "Does low birthweight predispose to Perthes' disease? Perthes' disease in twins," Journal of Pediatric Orthopaedics Part B, vol. 12, no. 5, pp. 307-310, 2003.

[64] D. S. Weiner and H. W. O’Dell, "Legg-Calvé-Perthes disease. Observations on skeletal maturation," Clinical Orthopaedics and Related Research, vol. 68, pp. 44-49, 1970.

[65] S. Motokawa, "Effect of serum factors on skeletal growth in Perthes' disease," Journal of the Japanese Orthopaedic Association, vol. 64, no. 9, pp. 790-797, 1990.

[66] G. Eckerwall, H. Wingstrand, G. Hägglund, and J. Karlberg, "Growth in 110 children with Legg-Calve-Perthes' disease: a longitudinal infancy childhood puberty growth model study," Journal of Pediatric Orthopaedics Part B, vol. 5, no. 3, pp. 181-184, 1996.

[67] F. Shapiro, "Legg-Calve-Perthes disease. A study of lower extremity length discrepancies and skeletal maturation," Acta Orthopaedica Scandinavica, vol. 53, no. 3, pp. 437-444, 1982.

[68] W. D. C. Kealey, K. J. Lappin, H. Leslie, B. Sheridan, and A. P. Cosgrove, "Endocrine profile and physical stature of children with Perthes disease," Journal of Pediatric Orthopaedics, vol. 24, no. 2, pp. 161-166, 2004.

[69] Z. Laron, A. Axer, and Z. Drezner, "Growth and development of children with Legg Calve Perthes syndrome in Israel," Israel Journal of Medical Sciences, vol. 9, no. 5, pp. 612-616, 1973.

[70] R. G. Burwell, P. H. Dangerfield, and D. J. Hall, "Perthes' disease. An anthropometric study revealing impaired and disproportionate growth," Journal of Bone and Joint Surgery. British, vol. 60, no. 4, pp. 461-477, 1978.

[71] A. J. Hall, D. J. P. Barker, P. H. Dangerfield, C. Osmond, and J. F. Taylor, "Small feet and Perthes' disease. A survey in Liverpool," Journal of Bone and Joint Surgery. British, vol. 70, no. 4, pp. 611-613, 1988.
[72] B. S. Rao, B. Joseph, V. Chacko, and A. J. Hall, "Altered skeletal growth in Perthes' disease: an anthropometric study of children from rural India," Journal of Pediatric Orthopaedics. Part B, vol. 4, no. 1, pp. 91-94, 1995.

[73] W. W. Greulich and S. I. Pyle, Radiographic Atlas of Skeletal Development of the Hand and Wrist, Stanford University Press, Stanford, Calif, USA, 2nd edition, 1959.

[74] R. M. Acheson, "The Oxford method of assessing skeletal maturity," Clinical orthopaedics, vol. 10, pp. 19-39, 1957.

[75] R. T. Loder, F. A. Farley, J. A. Herring, M. A. Schork, and Y. Shyr, "Bone age determination in children with Legg-CalvePerthes disease: a comparison of two methods," Journal of Pediatric Orthopaedics, vol. 15, no. 1, pp. 90-94, 1995.

[76] M. H. M. Harrison, M. H. Turner, and P. Jacobs, "Skeletal immaturity in Perthes' disease," Journal of Bone and Joint Surgery. British, vol. 58, no. 1, pp. 37-40, 1976.

[77] F. Kristmundsdottir, R. G. Burwell, D. J. Hall, and W. A. Marshall, "A longitudinal study of carpal bone development in Perthes' disease: its significance for both radiologic standstill and bilateral disease," Clinical Orthopaedics and Related Research, vol. 209, pp. 115-123, 1986.

[78] F. Kristmundsdottir, R. G. Burwell, and M. H. M. Harrison, "Delayed skeletal maturation in Perthes' disease," Acta Orthopaedica Scandinavica, vol. 58, no. 3, pp. 277-279, 1987.

[79] S. T. Lee, S. V. Vaidya, H. R. Song, S. H. Lee, S. W. Suh, and S. S. Telang, "Bone age delay patterns in legg-calvéperthes disease: an analysis using the tanner and whitehouse 3 method," Journal of Pediatric Orthopaedics, vol. 27, no. 2, pp. 198-203, 2007.

[80] V. M. R. Vila-Verde and K. C. Da Silva, "Bone age delay in Perthes disease and transient synovitis of the hip," Clinical Orthopaedics and Related Research, no. 385, pp. 118-123, 2001.

[81] N. A. N. Zarco, J. M. Morán, and M. A. Hernández, “Delay in skeletal maturity in Mexican patients with Legg-CalvéPerthes," Acta Ortopédica Mexicana, vol. 22, no. 3, pp. 157161, 2008.

[82] Y. Nishi, T. Tanaka, K. Fujieda et al., "Slipped capital femoral epiphysis, Perthes' disease and scoliosis in children with growth hormone deficiency," Endocrine Journal, vol. 45, pp. S167-S169, 1998.

[83] P. H. W. Rayner, S. L. Schwalbe, and D. J. Hall, "An assessment of endocrine function in boys with Perthes' disease," Clinical Orthopaedics and Related Research, vol. 209, pp. 124-128, 1986.

[84] H. Tanaka, K. Tamura, and K. Takano, "Serum somatomedin A in Perthes' disease," Acta Orthopaedica Scandinavica, vol. 55, no. 2, pp. 135-140, 1984.

[85] R. G. Burwell, C. L. Vernon, and P. H. Dangerfield, "Raised somatomedin activity in the serum of young boys with Perthes' disease revealed by bioassay: a disease of growth transition?" Clinical Orthopaedics and Related Research, vol. 209, pp. 129-138, 1986.

[86] T. Kitsugi, Y. Kasahara, Y. Seto, and S. Komai, "Normal somatomedin- $\mathrm{C}$ activity measured by radioimmunoassay in Perthes' disease," Clinical Orthopaedics and Related Research, no. 244, pp. 217-221, 1989.

[87] J. Neidel, D. Zander, and M. H. Hackenbroch, "Low plasma levels of insulin-like growth factor I in Perthes' disease. A controlled study of 59 consecutive children," Acta Orthopaedica Scandinavica, vol. 63, no. 4, pp. 393-398, 1992.

[88] J. Neidel, E. Schonau, D. Zander, J. Rutt, and M. H. Hackenbroch, "Normal plasma levels of IGF binding protein 
in Perthes' disease. Follow-up of previous report," Acta Orthopaedica Scandinavica, vol. 64, no. 5, pp. 540-542, 1993.

[89] P. M. Crofton, C. Macfarlane, B. Wardhaugh et al., "Children with acute Perthes' disease have asymmetrical lower leg growth and abnormal collagen turnover," Acta Orthopaedica, vol. 76, no. 6, pp. 841-847, 2005.

[90] T. Matsumoto, H. Enomoto, K. Takahashi, and S. Motokawa, "Decreased levels of IGF binding protein-3 in serum from children with Perthes' disease," Acta Orthopaedica Scandinavica, vol. 69, no. 2, pp. 125-128, 1998.

[91] H. Grasemann, R. D. Nicolai, B. P. Hauffa, W. Reinhardt, H. Nicolai, and M. Hövel, "Skeletal immaturity, IGF-I and IGFBP-3 serum concentrations in Legg-Calve-Perthes disease (skeletal immaturity, IGF-I and IGFBP-3 in LCPD)," Klinische Padiatrie, vol. 208, no. 6, pp. 339-343, 1996.

[92] T. T. Lahdes-Vasama, I. S. J. Sipilä, S. Lamminranta, S. H. Pihko, E. O. J. Merikanto, and E. J. Marttinen, "Psychosocial development and premorbid skeletal growth in legg-calveperthes disease: a study of nineteen patients," Journal of Pediatric Orthopaedics Part B, vol. 6, no. 2, pp. 133-137, 1997.

[93] R. W. Emerick, K. E. Corrigan, A. H. Joistad Jr., and L. E. Holly, "Thyroid function in Legg-Calve-Perthes disease-a new approach to an old problem," Clinical Orthopaedics and Related Research, vol. 4, pp. 160-165, 1954.

[94] L. A. Cavanaugh, E. K. Shelton, S. Barbara, and R. Sutherland, "Metabolic studies in osteochondritis of the capital femoral epiphysis," The Journal of Bone and Joint Surgery. American, vol. 18, pp. 957-968, 1936.

[95] A. B. Gill, "Relationship of Legg-Perthes disease to the function of the thyroid gland," The Journal of Bone and Joint Surgery. American, vol. 25-A, pp. 892-901, 1943.

[96] J. F. Katz, "Protein-bound iodine in Legg-Calvé-Perthes disease," The Journal of Bone and Joint Surgery. American, vol. 37, no. 4, pp. 842-846, 1955.

[97] D. D. Beiler and W. H. Love, "Thyroid function in LeggPerthes disease," The Journal of Bone and Joint Surgery. American, vol. 38, no. 6, pp. 1320-1322, 1956.

[98] E. M. Chapman, "Thyroid function in Legg-Perthes disease," The New England journal of medicine, vol. 255, no. 6, pp. 289290, 1956.

[99] S. Bahmanyar, S. M. Montgomery, R. J. Weiss, and A. Ekbom, "Maternal smoking during pregnancy, other prenatal and perinatal factors, and the risk of legg-calvé-perthes disease," Pediatrics, vol. 122, no. 2, pp. e459-e464, 2008.

[100] J. E. Gordon, P. L. Schoenecker, J. D. Osland, M. B. Dobbs, D. A. Szymanski, and S. J. Luhmann, "Smoking and socioeconomic status in the etiology and severity of Legg-CalvéPerthes' disease," Journal of Pediatric Orthopaedics Part B, vol. 13, no. 6, pp. 367-370, 2004.

[101] S. García Mata, E. Ardanaz Aicua, A. Hidalgo Ovejero, and M. Martinez Grande, "Legg-Calvé-Perthes disease and passive smoking," Journal of Pediatric Orthopaedics, vol. 20, no. 3, pp. 326-330, 2000.

[102] C. J. Glueck, R. A. Freiberg, A. Crawford et al., "Secondhand smoke, hypofibrinolysis, and Legg-Perthes disease," Clinical Orthopaedics and Related Research, no. 352, pp. 159-167, 1998.

[103] A. Dilley, W. C. Hooper, H. Austin et al., "The beta fibrinogen gene G-455-A polymorphism is a risk factor for Legg-Perthes disease," Journal of Thrombosis and Haemostasis, vol. 1, no. 11, pp. 2317-2321, 2003.

[104] R. M. Bertina, B. P. C. Koeleman, T. Koster et al., "Mutation in blood coagulation factor $\mathrm{V}$ associated with resistance to activated protein C," Nature, vol. 369, no. 6475, pp. 64-67, 1994.

[105] C. J. Glueck, T. Tracy, and P. Wang, "Legg-calve-perthes disease, venous and arterial thrombi, and the factor V leiden mutation in a four-generation kindred," Journal of Pediatric Orthopaedics, vol. 27, no. 7, pp. 834-837, 2007.

[106] R. Gruppo, C. J. Glueck, E. Wall, D. Roy, and P. Wang, "LeggPerthes disease in three siblings, two heterozygous and one homozygous for the factor V Leiden mutation," Journal of Pediatrics, vol. 132, no. 5, pp. 885-888, 1998.

[107] C. J. Glueck, G. Brandt, R. Gruppo et al., "Resistance to activated protein C and Legg-Perthes disease," Clinical Orthopaedics and Related Research, no. 338, pp. 139-152, 1997.

[108] K. Szepesi, E. Pósán, J. Hársfalvi et al., “The most severe forms of Perthes' disease associated with the homozygous Factor V Leiden mutation," Journal of Bone and Joint Surgery. British, vol. 86, no. 3, pp. 426-429, 2004.

[109] L. L. O. Sanders, M. B. Braga Júnior, C. W. M. Cima, R. M. S. Mota, M. I. M. C. Pardini, and S. H. B. Rabenhorst, "Leiden's V-factor in Legg-Calvé-Perthes disease," Acta Ortopedica Brasileira, vol. 17, no. 2, pp. 40-42, 2009.

[110] V. V. Balasa, R. A. Gruppo, C. J. Glueck et al., "Legg-CalvéPerthes disease and thrombophilia," Journal of Bone and Joint Surgery. American, vol. 86, no. 12, pp. 2642-2647, 2004.

[111] J. Eldridge, A. Dilley, H. Austin et al., "The role of protein $\mathrm{C}$, protein $\mathrm{S}$, and resistance to activated protein $\mathrm{C}$ in LeggPerthes disease," Pediatrics, vol. 107, no. 6, pp. 1329-1334, 2001.

[112] V. R. Arruda, W. D. Belangero, M. C. Ozelo et al., "Inherited risk factors for thrombophilia among children with LeggCalve-Perthes disease," Journal of Pediatric Orthopaedics, vol. 19, no. 1, pp. 84-87, 1999.

[113] A. Vosmaer, R. R. Pereira, J. S. Koenderman, F. R. Rosendaal, and S. C. Cannegieter, "Coagulation abnormalities in LeggCalvé-Perthes disease," Journal of Bone and Joint Surgery. American, vol. 92, no. 1, pp. 121-128, 2010.

[114] C. J. Glueck, H. I. Glueck, D. Greenfield et al., "Protein $\mathrm{C}$ and $\mathrm{S}$ deficiency, thrombophilia, and hypofibrinolysis: pathophysiologic causes of Legg-Perthes disease," Pediatric Research, vol. 35, no. 4, pp. 383-388, 1994.

[115] C. J. Glueck, A. Crawford, D. Roy, R. Freiberg, H. Glueck, and D. Stroop, "Association of antithrombotic factor deficiencies and hypofibrinolysis with Legg-Perthes disease," Journal of Bone and Joint Surgery. American, vol. 78, no. 1, pp. 3-13, 1996.

[116] K. H. Koo, H. R. Song, Y. C. Ha et al., "Role of thrombotic and fibrinolytic disorders in the etiology of Perthes' disease," Clinical Orthopaedics and Related Research, no. 399, pp. 162167, 2002.

[117] D. Yilmaz, L. Karapinar, B. Karapinar, H. Ozturk, and K. Kavakli, "Evaluation of anticoagulant system in Turkish children with Perthes disease," Pediatrics International, vol. 47, no. 1, pp. 43-48, 2005.

[118] W. D. C. Kealey, E. E. Mayne, W. McDonald, P. Murray, and A. P. Cosgrove, "The role of coagulation abnormalities in the development of Perthe's disease," Journal of Bone and Joint Surgery. British, vol. 82, no. 5, pp. 744-746, 2000.

[119] M. T. Hresko, P. A. McDougall, J. B. Gorlin, E. C. Vamvakas, J. R. Kasser, and E. J. Neufeld, "Prospective reevaluation of the association between thrombotic diathesis and legg-perthes disease," Journal of Bone and Joint Surgery. American, vol. 84, no. 9, pp. 1613-1618, 2002. 
[120] M. López-Franco, G. González-Morán, J. C. De Lucas et al., "Legg-Perthes disease and heritable thrombophilia," Journal of Pediatric Orthopaedics, vol. 25, no. 4, pp. 456-459, 2005.

[121] S. Gallistl, T. Reitinger, W. Linhart, and W. Muntean, "The role of inherited thrombotic disorders in the etiology of LeggCalve-Perthes disease," Journal of Pediatric Orthopaedics, vol. 19, no. 1, pp. 82-83, 1999.

[122] J. S. Mehta, M. E. Conybeare, B. L. Hinves, and J. B. M. Winter, "Protein C levels in patients with Legg-CalvePerthes disease: is it a true deficiency?" Journal of Pediatric Orthopaedics, vol. 26, no. 2, pp. 200-203, 2006.

[123] R. Shiba and S. Fujii, "Legg-Calve-Perthes in children. Letter to the editor," Clinical Orthopaedics and Related Research, vol. 363, pp. 268-269, 1999.

[124] G. Kenet, E. Ezra, S. Wientroub et al., "Perthes' disease and the search for genetic associations: collagen mutations, Gaucher's disease and thrombophilia," Journal of Bone and Joint Surgery. British, vol. 90, no. 11, pp. 1507-1511, 2008.

[125] S. Hayek, G. Kenet, A. Lubetsky, N. Rosenberg, S. Gitel, and S. Wientroub, "Does thrombophilia play an aetiological role in Legg-Calve-Perthes disease?" Journal of Bone and Joint Surgery. British, vol. 81, no. 4, pp. 686-690, 1999.

[126] N. Sirvent, F. Fisher, T. El Hayek, A. Appert, H. Giudicelli, and J. Griffet, "Absence of congenital prethrombotic disorders in children with Legg-Perthes disease," Journal of Pediatric Orthopaedics Part B, vol. 9, no. 1, pp. 24-27, 2000.

[127] M. A. Matos, "The role of protein C deficiency in the etiology of Perthes disease," Ortopedia Traumatologia Rehabilitacja, vol. 10, no. 3, pp. 274-278, 2008.

[128] M. C. Aksoy, D. Y. Aksoy, I. C. Haznedaroglu, N. Sayinalp, S. Kirazli, and M. Alpaslan, "Enhanced tissue factor pathway inhibitor response as a defense mechanism against ongoing local microvascular events of Legg-Calve-Perthes disease," Pediatric Hematology and Oncology, vol. 22, no. 5, pp. 391399, 2005.

[129] R. G. Kleinman and E. E. Bleck, "Increased blood viscosity in patients with Legg-Perthes disease: a preliminary report," Journal of Pediatric Orthopaedics, vol. 1, no. 2, pp. 131-136, 1981.

[130] M. C. Aksoy, D. Y. Aksoy, I. C. Haznedaroglu, N. Sayinalp, S. Kirazli, and M. Alpaslan, "Thrombomodulin and GFC levels in Legg-Calve-Perthes disease,” Hematology, vol. 13, no. 6, pp. 324-328, 2008.

[131] B. Westhoff, R. Krauspe, A. E. Kalke et al., "Urinary excretion of deoxypyridinoline in Perthes' disease. A prospective, controlled comparative study in 83 children," Journal of Bone and Joint Surgery. British, vol. 88, no. 7, pp. 967-971, 2006.

[132] I. Orfanos, C. Magkou, I. Anastasopoulos, E. Karanikas, and N. M. Sitaras, "Urine glycosaminoglycans in children with transient hip synovitis and Perthes disease," Journal of Pediatric Orthopaedics Part B, vol. 14, no. 2, pp. 92-96, 2005.

[133] G. Eckerwall, L. Stefan Lohmander, and H. Wingstrand, "Increased levels of proteoglycan fragments and stromelysin in hip joint fluid in Legg-Calve-Perthes disease," Journal of Pediatric Orthopaedics, vol. 17, no. 2, pp. 266-269, 1997.

[134] M. H. M. Harrison and M. E. Blakemore, "A study of the 'normal' hip in children with unilateral Perthes' disease," Journal of Bone and Joint Surgery. British, vol. 62, no. 1, pp. 31-36, 1980.

[135] E. Arie, F. Johnson, and M. H. M. Harrison, "Femoral head shape in Perthes' disease: is the contralateral hip abnormal?" Clinical Orthopaedics and Related Research, vol. 209, pp. 77$88,1986$.
[136] G. Kandzierski, T. Karski, and K. Kozlowski, "Capital femoral epiphysis and growth plate of the asymptomatic hip joint in unilateral Perthes disease," Journal of Pediatric Orthopaedics Part B, vol. 12, no. 6, pp. 380-386, 2003.

[137] H. Kitoh, T. Kitakoji, M. Katoh, and Y. Takamine, "Delayed ossification of the proximal capital femoral epiphysis in LeggCalvé-Perthes' disease," Journal of Bone and Joint Surgery. British, vol. 85, no. 1, pp. 121-124, 2003.

[138] W. E. Fitzgerald, A psychological factor in Legg-Perthes-Calvé disease, Ph.D. thesis, Harvard University, Boston, Mass, USA, 1961.

[139] R. T. Loder, E. M. Schwartz, and R. N. Hensinger, "Behavioral characteristics of children with Legg-Calve-Perthes disease," Journal of Pediatric Orthopaedics, vol. 13, no. 5, pp. 598-601, 1993.

[140] A. Catterall, G. C. Roberts, and R. Wynne-Davies, "Association of Perthes' disease with congenital anomalies of genitourinary tract and inguinal region," Lancet, vol. 1, no. 7707, pp. 996-997, 1971.

[141] M. Makin, S. Meyer, and A. N. Gilai, "Perthes' disease and posterior lumbosacral union," Journal of Pediatric Orthopaedics, vol. 12, no. 5, pp. 607-609, 1992.

[142] J. F. Katz, "Spina bifida occulta in Legg-Calvé-Perthes disease," Clinical Orthopaedics and Related Research, vol. 14, pp. 110-118, 1959.

[143] H. Kitoh, T. Kitakoji, M. Katoh, and N. Ishiguro, "Sagittal spinal alignment in patients with Legg-Calve-Perthes disease," Pediatrics International, vol. 49, no. 5, pp. 612-617, 2007.

[144] A. J. Hall, B. M. Margetts, D. J. P. Barker et al., "Low blood manganese levels in Liverpool children with Perthes' disease," Paediatric and Perinatal Epidemiology, vol. 3, no. 2, pp. 131136, 1989.

[145] C. A. Perry, J. F. Taylor, A. Nunn, P. H. Dangerfield, and H. Delves, "Perthes' disease and blood manganese levels," Archives of Disease in Childhood, vol. 82, no. 5, pp. 429-430, 2000.

[146] B. Joseph, "Serum immunoglobulin in Perthes' disease," Journal of Bone and Joint Surgery. British, vol. 73, no. 3, pp. 509-510, 1991.

[147] J. A. Matsoukas, "Viral antibody titers to rubella in coxa plana or Perthes' disease. Perthes' disease: is it the late osseous residua of a minor prenatal rubella?" Acta Orthopaedica Scandinavica, vol. 46, no. 6, pp. 957-962, 1975.

[148] W. Jansen and A. A. J. M. Hazebroek-Kampschreur, "Differences in height and weight between children living in neighbourhoods of different socioeconomic status," Acta Paediatrica, vol. 86, no. 2, pp. 224-225, 1997. 


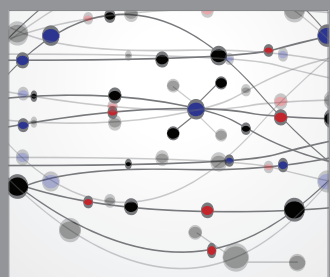

The Scientific World Journal
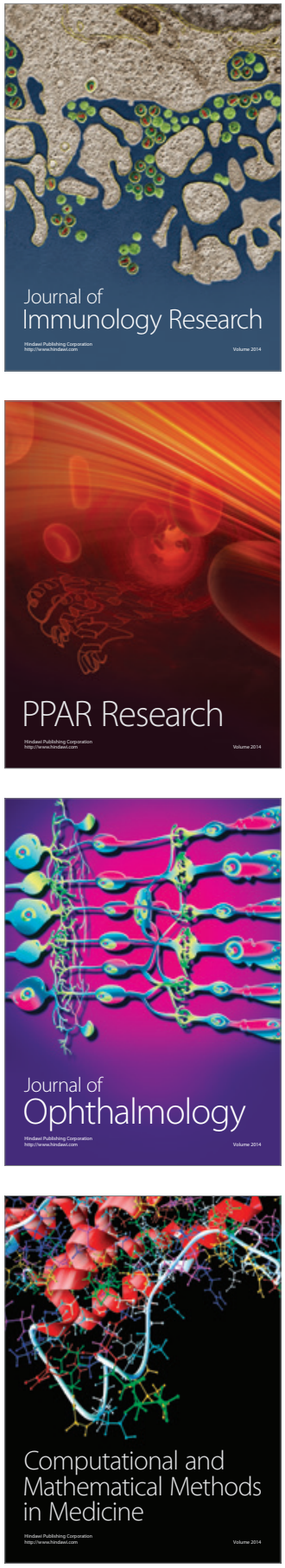

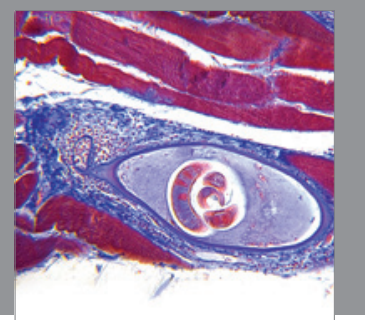

Gastroenterology

Research and Practice
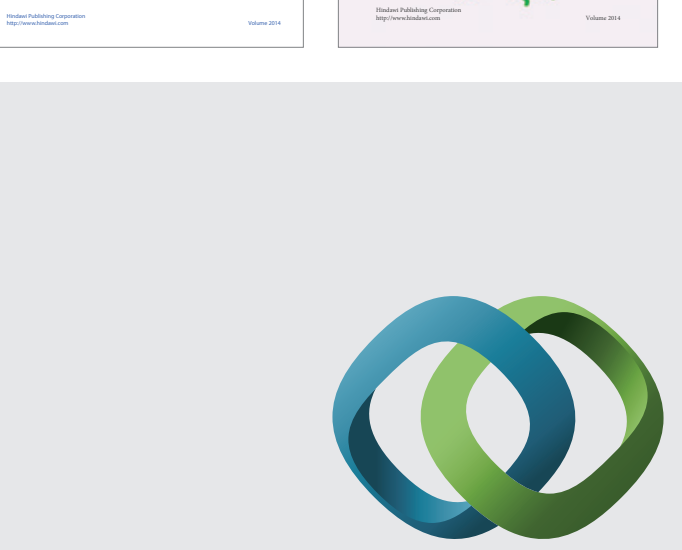

\section{Hindawi}

Submit your manuscripts at

http://www.hindawi.com
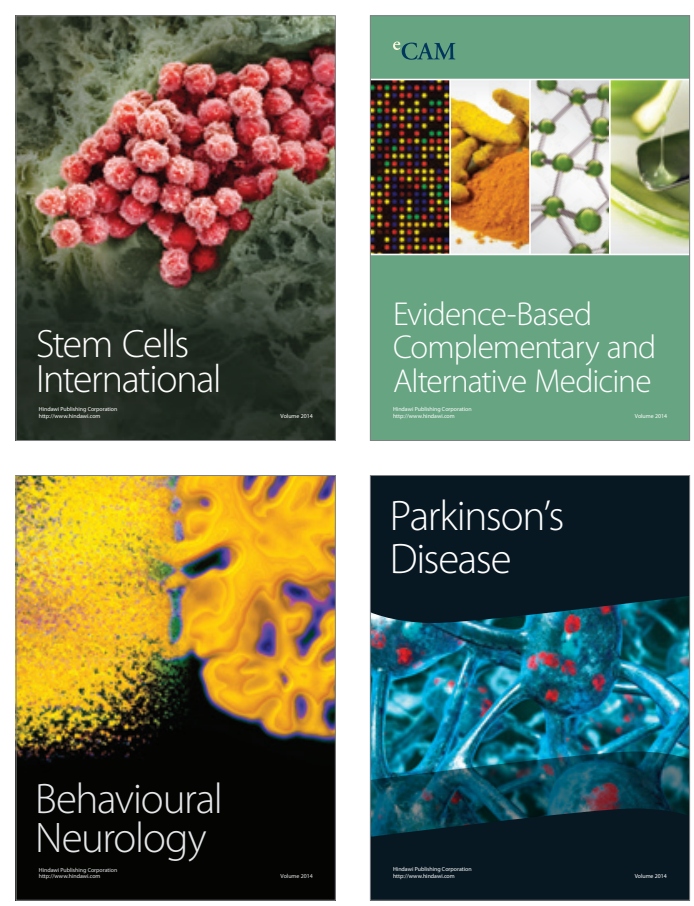

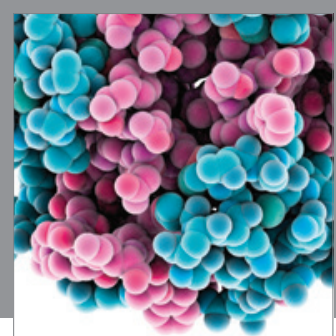

Journal of
Diabetes Research

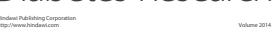

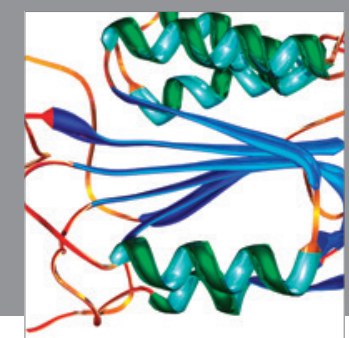

Disease Markers
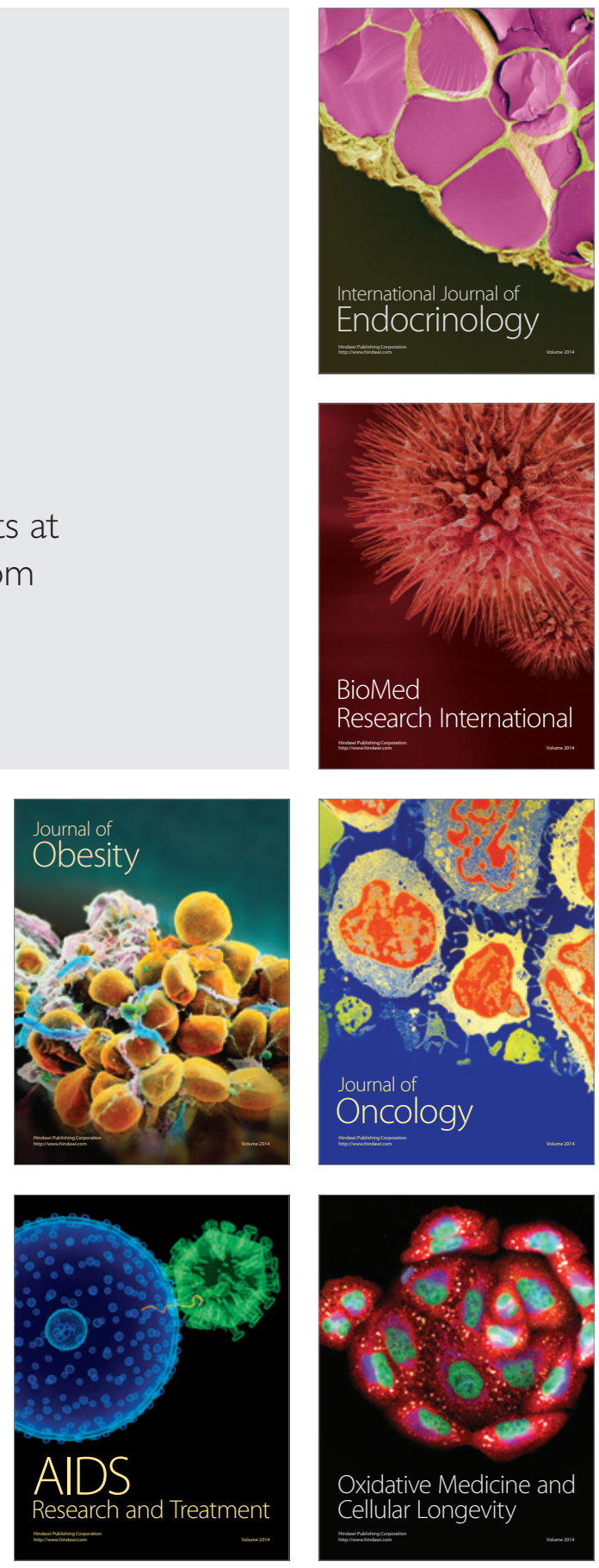